\author{
YANINA ALEKSANDROVNA DMITRAKOVA ${ }^{1}$, OKSANA ANDREEVNA RODINA ${ }^{1}$, \\ IVAN ILYCH ALEKSEEV ${ }^{1}$, VYACHESLAV IGOREVICH POLYAKOV ${ }^{1}$, \\ ALINA ALEKSANDROVNA PETROVA ${ }^{1}$, EKATERINA VLADIMIROVNA PERSHINA ${ }^{1}$, \\ EKATERINA ANDREEVNA IVANOVA ${ }^{1}$, EVGENY VASILEVICH ABAKUMOV ${ }^{1 *}$, \\ JAKUB KOSTECKI ${ }^{2}$
}

\author{
${ }^{1}$ Saint Petersburg State University, Department of Applied Ecology \\ 16 line 29 Vasilyevskiy Island, 199178, Saint-Petersburg, Russia \\ ${ }^{2}$ University of Zielona Góra, Department of Environmental Engineering 15 \\ Prof. Z. Szafrana Str., 65-516 Zielona Góra, Poland
}

\title{
Restoration of soil-vegetation cover and soil microbial community at the Pechurki limestone quarry (Leningrad region, Russia)
}

\begin{abstract}
Due to a significant increase in mining activity and subsequent ecosystem disturbances, it is becoming increasingly important to understand how degraded, unproductive quarries can be converted into new, self-sustaining communities that develop into natural environments. Former limestone quarry was investigated with aim to determine the best reclamation practice for surfaces of former lime rock quarries. Effects of spontaneous succession and forestry reclamation restoration approaches on vegetation and soil features were studied. The study was conducted in one of the largest limestone quarries of the Leningrad region, south taiga region. Species composition and vegetation cover were estimated for different plant communities within each ecotype of the quarry. Also soil characteristics were evaluated at each plot. We found that the main differences between plots were due to their position in the landscape; the most similar communities colonize similar ecotypes. On flat landforms, biodiversity is reduced under biological reclamation. At the sites under spontaneous succession, the level of biodiversity increases. In terms of biodiversity conservation and economic benefit, spontaneous succession is preferable to forestry reclamation for the restoration of carbonate substrates. After examining $\mathrm{CO}_{2}$ emissions from the quarry as a result of weathering of carbonates and soil respiration, as well as the level of $\mathrm{CO}_{2}$ sequestration from the atmosphere, we show that the establishment of certain landscape forms within former quarries can help to reduce atmospheric $\mathrm{CO}_{2}$.
\end{abstract}

Keywords: soil restoration, reclamation, quarries, diversity of microbial communities, technogenic soils

\section{INTRODUCTION}

Quarries are considered as examples of extreme ecosystem disturbance. The total area occupied by mining explorations has rapidly increased over recent centuries and continues to grow (̌̌ehounková et al. 2016). The open method of exploration is known as extensively used for mining activity because it facilitates complete and economically effective extraction (Mudd 2010). Quarrying operations can increase dust emission and noise pollution. In addition, mining activity can profoundly alter preexisting communities and perturb hydro-geological and hydrological regimes (Shaban et al. 2007, Abakumov et al. 2016, Abakumov et al. 2015, Kurá• et al. 2012). Quarrying can profoundly change the soil surface (Stehouwer et al. 2006), modify the landscape (Jomaa et al. 2008, Abakumov et al. 2015), eliminate natural habitats, and discontinue natural succession (Khater et al. 2003), as well as shift genetic resources (El-Fadel et al. 2000, Abakumov et al. 2013).
Recovery of the vast majority of quarries is typically slow, and large areas often remain bare after decades of abandonment (Williamson et al. 2003). The major limiting factors for the establishment of plant communities at abandoned quarries are low nutrient availability and unfavorable physical properties of the soil (Sheldon 1975). A recovered community must be able to develop through natural processes, without human input (Berger 1993). The restored ecosystem should have tolerance for stress and should include an assemblage of native species (Jomaa et al. 2008). Species of plants should be able to grow under conditions of rocky ground, in nutrientand water-poor soil, in soils of extreme $\mathrm{pH}$, and on steep slopes. Because of the severity of disturbances in quarries, plant succession is slow, requiring up to several centuries. Different abandoned quarry restoration approaches might lead to differences in biodiversity and ecological functions.

The vast majority of studies for quarries and similar disturbances have focused on the effect of seeding or 
transplanting various species of plants (Gretarsdottir et al. 2004, Tormo et al. 2007), including nitrogenfixing plants, such as legumes and alders (Smyth 1997). These studies have produced mixed results. Although the successful establishment of the transplanted trees and shrubs is often reported, this is not conducive to the recovery of the ecosystem by colonization by native species. The introduced species might remain dominant, which causes the restored ecosystems to be characterized by low diversity (Bishop and Chapin 1989; Brown and Rice 2000; Densmore 1992) or as landscapes atypical for a given region. Some researchers suppose that reclamation through spontaneous succession (rather than forestry restoration) favors biodiversity (Řehounková et al. 2016, Dmitrakova et al. 2018b).

Some remediation studies have suggested that biodiversity is an important ecological factor for mining sustainability (Johnson 2006) and that efficient techniques leading to the recovery of ecological processes and biodiversity are imperative. These finding could be extrapolated to other limestone quarries. Here the limestones industrial exploitations are knowns as the most ancient in Russia (up to 300 years), that is why numerous limestone quarries are located on the macro landscape of Izhora Plateau.

Quarry restoration is a complicated process. The starting area is usually bare and consists of a lowfertile substrate (Tischew and Kirmer 2007; Dmitrakova et al. 2018a). Therefore, it is important to determine the optimal restoration approaches when planning a successful ecological recreation. This includes detailed quantitative case studies, field experiments, and comparative studies over wide geographical areas (Prach 2003).

The spontaneous succession of plant communities in quarries with various substrates has been studied in sufficient detail. Much of the research is devoted to various aspects of succession of the vegetation cover (Kopceva 2005, Neshataev et al. 2012, Sumina 2013), the processes of pedogenesis have been analyzed quite thoroughly (Abakumov et al. 2013, Yarwood et al. 2015). However, complex observations on the restoration of the soil and vegetation cover and the connection of these components remain small. In contrast, other works are focused on the conjugate development of soil and vegetation cover, but not due to overgrowth, but after planting certain plant species (Labbe et al. 1995, Laitinen et al. 2008, Gretarsdottir et al. 2004, Tormo et al. 2007). Traditionally, articles about land reclamation focused on the study of vegetation cover and the redistribution of soil organic matter (Archegova 2013, Androhanov 2000). The importance of microbiom in ecosystem restoration processes has long been underestimated. In the last decade, many publications (Stifeev et al. 2011, Dangi et al. 2012, Acosta-Martinez et al. 2010) have been devoted to the study of the microbial communities of reclaimed soils, containing valuable information on the rates of biomass restoration and the activity of microbial communities in the chronosequence of soils in technogenic landscapes (Liu et al. 2016, Li et al. 2014, Luna et al. 2016). It is shown that the structure and composition of microbioms are determined by a combination of physical and agrochemical parameters (reserves of soil organic matter, total nitrogen, $\mathrm{pH}$, cation exchange capacity of soils), whose values are significantly higher in reclaimed variants. Much attention is paid to the use of microbial communities as indicators of various stages of soil restoration of technogenic landscapes (Fierer et al. 2012, Zhang et al. 2011). At the same time, the diversity and structure of microbioms in disturbed and reclaimed soils is still insufficiently studied. Only with the advent of metagenomic technologies it became possible to effectively analyze and interpret the diversity of soil microbiota. Involvement of the diversity of soil microbiom in the study creates prospects for the development of qualitatively new systems for accelerating and optimizing remediation measures in disturbed areas. Recently, attention has been paid to the creation of microbial preparations to improve the quality of soils (Burns et al. 2013).

The aim of this study was a comprehensive analysis of the geo- and bio-diversity of a limestone quarry in order to determine the preferred method of reclamation. To achieve this goal, following objectives were stated: (1) to identify the main landforms of the quarry; (2) to evaluate the relationship between geo(diversity of ecotypes) and bio-diversity; (3) to define the basic physical and chemical properties of the soil; and (4) to determine the quantitative composition of the microbial communities.

\section{MATERIALS AND METHODS}

\section{Study sites}

The investigation has been conducted on the Pechurki limestone quarry $\left(59^{\circ} 08^{\prime} 02.7^{\prime \prime} \mathrm{N} 27^{\circ} 58^{\circ} 06.5^{\prime \prime E}\right)$ during the spring and summer season of 2016. The area is characterized by Atlantic-continental climate (average annual temperature of $2^{\circ} \mathrm{C}$ and average annual precipitation of $700 \mathrm{~mm}$ per year, evaporation rate is about $450 \mathrm{~mm}$ ). The climate characteristics are caused by the proximity to the sea, with moderately cold winters and warm summers. The natural soil 
cover of the region is mainly characterized by the predominance of Podzols (IUSS WRB 2015) that have developed on acid moraine tills or fluvioglacial deposits, but in region of Izhora Plateau also Calcaric Leptosols are typical due to the exposition of limestone derived parent materials of the surface (Ivlev 1994).

The main type of vegetation belongs to southern taiga with coniferous forests, but a high frequency of natural and anthropogenic disturbances has led to the establishment of small-leaved forests. Ecosystems of Izhora Plateau also characterizes by presence some representative of sub-boreal flora due to increased content of carbonates in local parent materials.

The Pechurki quarry is situated in Slantsy Town in the Leningrad region. Production of limestone was stopped in 2014 but biological reclamation was initiated already in 1970 and, in the course of this work, pine was planted on the dumps. Therefore, there are now reclaimed plots at various stages of overgrowing. However, the vast majority of the quarry area has undergone spontaneous revegetation. First, we identified all of the landforms of the quarry. Soil samples were collected from 12 key plots (Fig. 1) formed at 12 different sites under common plant communities (Fig. 2), where A - Umbric Leptosols (Calcaric) under accumulative self-overgrowing ecotope, overgrowing age is about 35 years, B - Leptosols (Skeletic, Calcaric) under self-overgrowing bottom of the quarry, overgrowing age is 29 years. Since the small-scale topographical differences strongly affect the soil and vegetation succession dynamics (Burga et al. 2010), plots with different topographic features were chosen. Field descriptions of the soil pits were made. Soil materials were collected from each horizon (in total of 33 soil samples). An inventory of the quarry flora was conducted. On each ecotype, we established sites of $25 \times 25 \mathrm{~m}$. Within each site, we determined all species of plants, on-soils mosses, total projective cover, and the projective cover of each species.

FIGURE 1. Schematic map of landforms on the quarry and location of the study sites

Sites: 1, 3, 4, 12 - self overgrowing dumps; 2 - self overgrowing terraced plot; 5, 6 - self overgrowing accumulative ecotopes on a soft overburden 7, 9, 10 - reclaimed terraced plots; 8,11 - rocky bottom
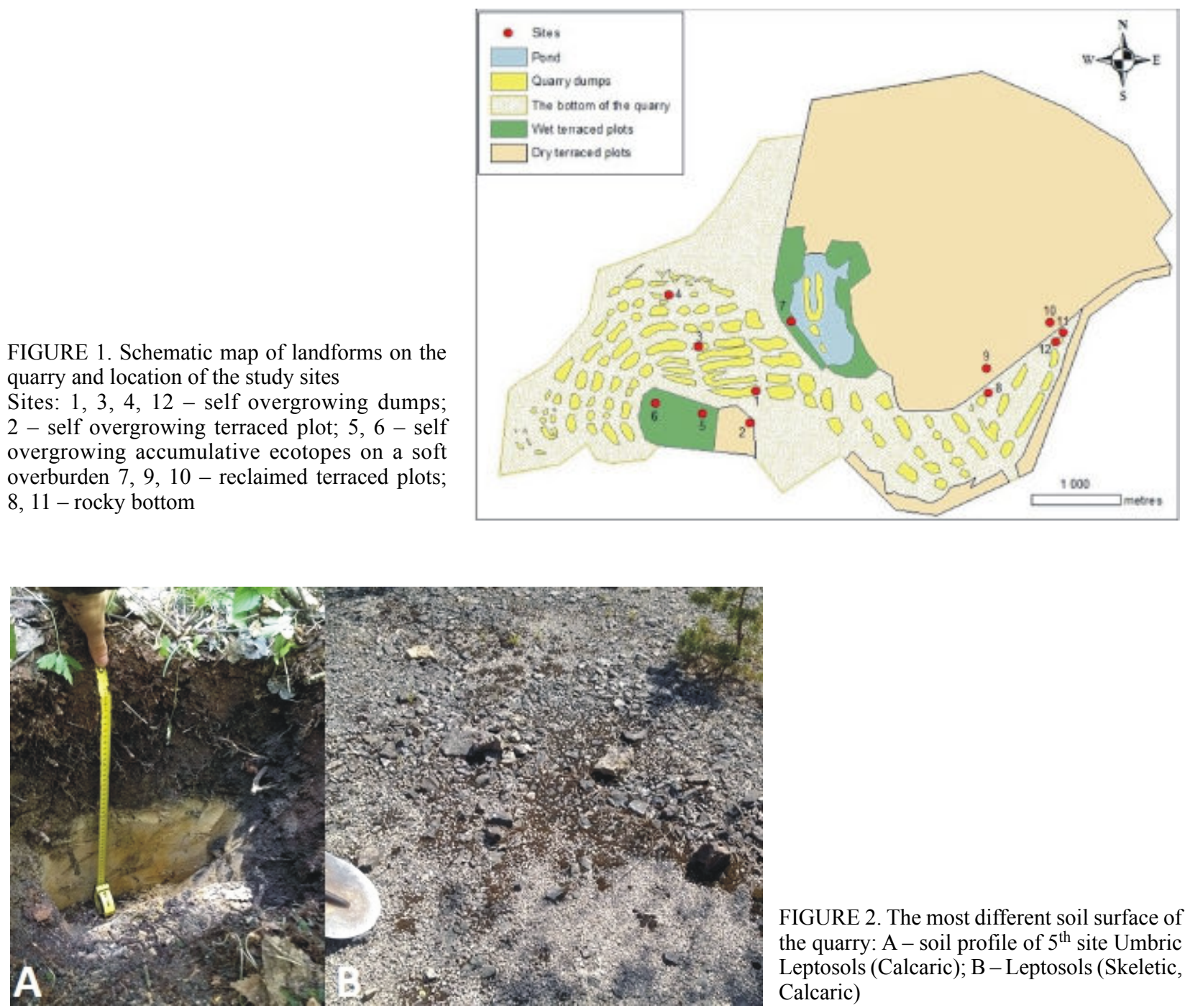

FIGURE 2. The most different soil surface of the quarry: A - soil profile of $5^{\text {th }}$ site Umbric Leptosols (Calcaric); B - Leptosols (Skeletic, Calcaric) 


\section{Laboratory analyses}

Mesomorphological description of soils and determination of the physical-chemical properties of soils were performed in the laboratory of the Department of Applied Ecology (Saint Petersburg State University). Soil samples were grounded and passed through a 2-mm sieve.

The following parameters were determined in soil samples: $\mathrm{pH}$ in water and salt $(\mathrm{KCl})$ suspension (1:2.5), skeletal fraction content, particle size distribution of the soil using pipette method by Kaczynski with pyrophosphate peptization of microaggregates (Rastvorova 1983), organic carbon oxidation by the bichromate (Walkey and Blake) method, substrateinduced respiration (Ananyeva et al. 2008), basal soil respiration, acidometric evaluation of $\mathrm{CO}_{2}$ content in carbonates (Tsitovich 1994), fractional-group composition of humus by Tyurin's scheme modified by Ponomareva and Plotnikova with extraction of groups of humic and fulvic acids (Ponomareva and Plotnikova 1980), quantitative determination of carbon of microbial biomass (Cmic) according to the formula proposed by Anderson and Domsch (1978), Cmic $\left(\mathrm{g} \mathrm{C} \mathrm{g}^{-1}\right.$ soil $)=\operatorname{LED}\left(\mathrm{L} \mathrm{CO}_{2} / \mathrm{g}_{\text {soil h}}{ }^{-1}\right) \times 40.04$ +0.37 , microbial metabolic rate (the specific respiration microbial biomass, $\mathrm{qCO}_{2}$ ) is found as the ratio of basal respiration to microbial biomass carbon index: $\mathrm{qCO}_{2}$

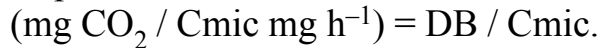

DNA extraction was performed using the PowerSoil DNA Isolation Kit (MO BIO, USA), which included a mechanical destruction step using abrasive materials (Mobio Laboratories, USA). The destruction of the soil sample was carried out on a Precellys 24 homogenizer (Bertin Technologies, France). The purity of isolation and the amount of isolated DNA were checked by electrophoresis in 1\% agarose in $0.5 \times$ TAE buffer. The average DNA concentration in the sample was $50 \mathrm{ng} \mathrm{cm}^{-3}$.

The purified DNA preparations (10-15 ng) were used as templates in the PCR reaction (temperature profile: $95^{\circ} \mathrm{C}$ for $30 \mathrm{~s}, 50^{\circ} \mathrm{C}$ for $30 \mathrm{~s}, 72^{\circ} \mathrm{C}$ for $30 \mathrm{~s}$, 30 cycles in total) using Encyclo polymerase (Eurogen, Russia) and universal primers to the V4 variable region of the 16S rRNA gene: F515 (GTGCCAGCMGCCGCGGTAA) and R806 (GGACTACVSGGGTATCTAAT) (Bates et al. 2010). The primers included oligonucleotide barcodes for each sample and the service sequences required for 454-pyrosequencing by «Roche» protocol (Roche, Switzerland). Sample preparation and sequencing were performed on a GS Junior device (Roche, Switzerland) according to the manufacturer's recommendations.

\section{Data analysis}

We have tested the significance of environmental factors using the direct selection approach (forward selection). Using only significant variables, we performed an analysis of correspondence (CCA) to establish how environmental factors affect the distribution of plant communities. Calculations were performed using Statistica 7 and Excel software programs.

We also considered those species that have not been described but fixed by descriptive routine method. We also conducted an ecological-phytocenotic analysis of vegetation. Types of living forms have been determined according to Cvelev (2000). For the purpose of estimating species composition, the similarity of vegetation on different key plots was calculated by the Sorensen-Chekanovsky coefficient. For the estimation of diversity on different key plots, Simpson's inverse ratio index and Shannon's index were calculated.

Downstream processing of the 16S rRNA gene libraries was performed using the QIIME software package (Caporaso et al. 2010). At the first stage, the sequence quality was verified: sequences smaller than 200 nucleotides in length, with a quality score of less than 25 , containing incorrectly read primer and multiplex identifier sequences, as well as extended homopolymeric repeats (more than eight nucleotides) and unidentified nucleotides were excluded from the analysis. All non-bacterial and chimeric sequences were excluded from the analysis; the data were normalized according to the number of sequences in the library of the smallest size. As a result of all of these procedures, 14,312 sequences were selected. After the data normalization procedure, the number of sequences in each library was 4700 . Sequences with similarity over $97 \%$ were combined into operational taxonomic units (OTU) using a de novo algorithm (based on the UCLUST method). From each OTU, one sequence was chosen to compose a set of representatives. The next stage was the classification of representative sequences using the RDP nad've Bayesian rRNA Classifier program and PyNast algorithm alignment (Caporaso et al. 2010), and a specially designed set of sequences, the Greengenes core set (DeSantis et al. 2006), was used to align the sequences. The aligned sequences were used to construct the distance matrix and phylogenetic tree.

To assess biodiversity and conduct a comparative analysis of communities, the parameters of $\alpha$-and $\beta$-diversity were calculated. The $\alpha$-diversity was assessed using the index of species richness (the number of OTUs in the sample) and the Shannon index. The 
reliability of differences in $\alpha$-diversity indices among microbiomes was assessed using the t-test. To assess the $\alpha$-diversity, we used the weighted UniFrac method, which allows estimating the percentage of similarities/differences between all pairs of compared microbiomes (Lozupone and Knight 2005). To represent the results of the analysis, we used a multidimensional statistics approach (analysis of the main components) using the Emperor program.

To assess the reliability of differences in the representation of individual taxa in the analyzed samples, in addition to the QIIME software, a script was written using the Python programming language. This script performs multiple pairwise tests of contingency tables of OUT frequencies in different collections of samples/replicates. The algorithm dynamically chooses either the G-test or the Fisher exact test depending on the circumstances and applies Bonferroni p-value correction.

\section{RESULTS}

\section{Soil surfaces diversity and spatial distribution}

The quarry has a different landscapes and a variety of ecotopes (Fig. 3).

We detected a high diversity of soil surfaces in the quarry, supporting the multivariate model of ecosystem development. Physical and chemical properties of the studied soil substrate and the results of our mezomorphological studies show relatively high rates of pedogenic substrate conversion. Organic matter accumulation in surface horizons increased with age and $\mathrm{pH}$ values decreased to 5.0 (Table 1). Surprisingly, the lowest $\mathrm{pH}$ values were found in the topsoils on the relatively elevated landforms (Sites 1, 2, and 4). In these plots, the dominant species are Populus tremula and Betula pendula.

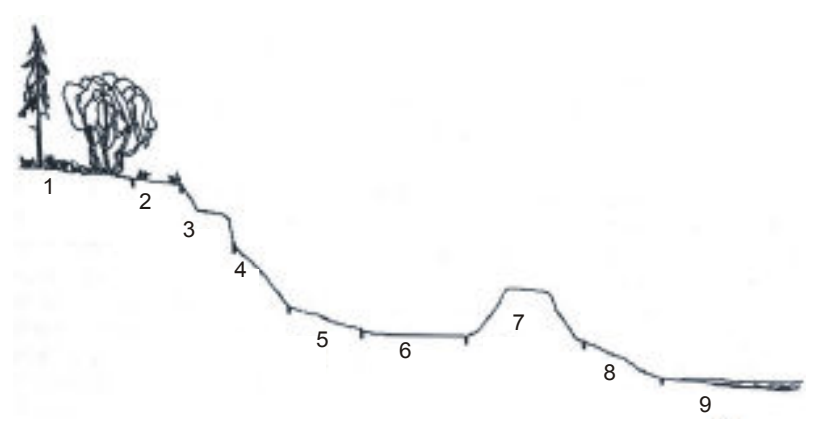

FIGURE 3. Ecotopes diversity of quarry (Sumina, 2013): 1 - undisturbed community; 2 - peripheral part; 3-5, 8 - transittrans eluvial ecotopes (slopes of different steepness and exposure); 6 - accumulative terraced areas; 7 - eluvial ecotopes (dumps); 9 - ponds
All areas were characterized by an extremely inhomogeneous distribution of the fractions in the profile. For all sites, there was a large amount of coarse skeletal material at a relatively low content of fine earth. The variation of stoniness (from $4.5 \%$ in the remediated sites up to $80 \%$ on the self-overgrowing bottom) demonstrates the high heterogeneity of the conditions at the quarry. This indicator is strongly dependent on the applied remediation technology.

High $\mathrm{CO}_{2}$ emissions is a negative consequence of mining; this is especially true for carbonate rocks. The release of carbon dioxide into the atmosphere can be estimated by the weathering of carbonates and soil basal respiration. In the process of development of soil and vegetation, emissions of carbon dioxide are changed by its sequestration, the rate of the last one can be estimated on the content of organic carbon in the soil. The basal respiration rate of the quarry soil was extremely low (from 0.015 to $0.1 \mathrm{mg}$ $\mathrm{CO}_{2} \mathrm{~g}^{-1}$ soil h${ }^{-1}$ ). The main sources of $\mathrm{CO}_{2}$ released into the atmosphere are weathered carbonates. The $\mathrm{CO}_{2}$ content of carbonate varies from 0.06 to $0.5 \%$. The highest levels of carbon dioxide deposition were observed at Site 6. This site is an accumulative ecotype with optimal moisture conditions and physical parameters of the substrate. The relatively high clay content and humification processes contribute to the carbon content in the soil, as well as the retention of stable forms of carbon. The maximum content of humic acid $(\mathrm{Cha} / \mathrm{Cfa}$ ratio $=0.91-0.80)$ was observed on the self-overgrowing dumps under small-leaved forests. A relatively large amount of fulvic acid $(\mathrm{Cha} / \mathrm{Cfa}=0.57)$ was typical for the site 9 , corresponding to the remediated site under the pine trees.

The status of the microbial communities at the quarries is poorly understood. This is problematic because microbial communities play critical roles in maintaining the sustainability of communities and ecosystem development. Therefore, studies addressing the state of a microbiological component of man-made habitats is particularly relevant. The microbial biomass content ranged from 0.98 to $4.60 \mathrm{~g} \mathrm{C} / \mathrm{g}$ soil. Although we were unable to identify any trends in microbiological criteria based on the type of vegetation or landforms, values tended to increase with time of overgrowing. Since the basal respiration and microbial biomass content depends largely on parameters such as humidity and temperature (Prihodko and Sizemskaya 2015), we calculated the microbial metabolic rate, which refers to integral biological indicators of soil. The values of this index ranged from 0.004 to $0.022 \mathrm{mg} \mathrm{CO} \mathrm{C}_{2} \mathrm{mg} \mathrm{C} \mathrm{mic/} \mathrm{h}$. 
TABLE 1. Physical and chemical properties of the studied soil substrates

\begin{tabular}{|c|c|c|c|c|c|c|c|c|c|c|c|}
\hline Sites & Horizon & $\begin{array}{l}\text { Depth } \\
\mathrm{cm}\end{array}$ & $\mathrm{pH}$ in $\mathrm{H}_{2} \mathrm{O}$ & $\begin{array}{l}\mathrm{CO}_{2} \\
\%\end{array}$ & $\begin{array}{l}\mathrm{OC} \\
\%\end{array}$ & Cha/Cfa & $\begin{array}{l}\text { Basal } \\
\text { respiration } \\
\operatorname{mgCO}_{2} \\
\mathrm{~g}^{-1} \mathrm{soil} \mathrm{h}^{-1}\end{array}$ & $\begin{array}{l}\text { Substrate- } \\
\text { induced } \\
\text { respiration }\end{array}$ & $\begin{array}{l}\text { Cmic } \\
(\mathrm{mkg} \\
\mathrm{C} \mathrm{g}^{-1} \\
\text { soil) }\end{array}$ & $\begin{array}{l}\mathrm{qCO}_{2} \\
\left(\mathrm{mkg} \mathrm{CO}_{2}\right. \\
\mathrm{Cg}^{-1} \\
\left.\mathrm{~h}^{-1}\right)\end{array}$ & $\begin{array}{l}\text { Coarse } \\
\text { fraction } \\
\text { contnet } \\
\%\end{array}$ \\
\hline \multirow[t]{4}{*}{1} & $\mathrm{O}$ & $0-4$ & 5.0 & 0.00 & 8.16 & 0.85 & 0.07 & 0.07 & 3.23 & 0.021 & 13.1 \\
\hline & $\mathrm{A}$ & $4-33$ & 4.4 & 0.06 & 6.79 & - & 0.03 & 0.03 & 1.70 & 0.018 & \\
\hline & $\mathrm{C} 1$ & $33-48$ & 5.7 & 0.10 & 1.19 & - & 0.02 & 0.02 & 1.19 & 0.017 & \\
\hline & $\mathrm{C} 2$ & $48 \downarrow$ & 7.5 & 0.17 & 0.86 & - & 0.03 & 0.03 & 1.49 & 0.017 & \\
\hline \multirow[t]{3}{*}{2} & $\mathrm{O}$ & $0-3$ & 5.3 & 0.00 & 1.69 & 0.76 & 0.11 & 0.12 & 5.06 & 0.022 & 30.5 \\
\hline & $\mathrm{Bs}$ & $3-13$ & 6.4 & 0.24 & 5.73 & - & 0.04 & 0.04 & 2.10 & 0.019 & \\
\hline & $\mathrm{C}$ & $13 \downarrow$ & 6.6 & 0.08 & 2.05 & - & 0.04 & 0.04 & 1.80 & 0.020 & \\
\hline \multirow[t]{5}{*}{3} & $\mathrm{O}$ & $0-7$ & 6.4 & 0.10 & 3.27 & 0.78 & 0.04 & 0.05 & 2.21 & 0.018 & 6.9 \\
\hline & $\mathrm{A}$ & $7-15$ & 5.9 & 0.10 & 7.85 & - & 0.02 & 0.03 & 1.49 & 0.015 & \\
\hline & $\mathrm{Bg}$ & $15-36$ & 6.4 & 0.07 & 0.65 & - & 0.06 & 0.07 & 3.02 & 0.020 & \\
\hline & $\mathrm{Bg}, \mathrm{r}$ & $36-45$ & 6.1 & 0.08 & 1.94 & - & 0.04 & 0.04 & 2.00 & 0.019 & \\
\hline & $\mathrm{C}$ & $45 \downarrow$ & 6.5 & 0.09 & 5.45 & - & 0.02 & 0.02 & 0.98 & 0.016 & \\
\hline \multirow[t]{2}{*}{4} & $\mathrm{~A}$ & $0-26$ & 5.2 & 0.21 & 3.94 & 0.91 & 0.04 & 0.05 & 2.21 & 0.018 & 29.5 \\
\hline & $\mathrm{AC}$ & $26+$ & 6.3 & 0.16 & 6.32 & - & 0.02 & 0.02 & 0.98 & 0.016 & \\
\hline \multirow[t]{4}{*}{5} & $\mathrm{O}$ & $0-13$ & 5.6 & 0.00 & 14.4 & 0.65 & 0.04 & 0.05 & 2.21 & 0.020 & 28.0 \\
\hline & $\mathrm{A}$ & $13-25$ & 6.1 & 0.35 & 2.13 & - & 0.06 & 0.07 & 3.02 & 0.021 & \\
\hline & $\mathrm{C}$ & $25-37$ & 5.8 & 0.08 & 0.67 & - & 0.02 & 0.03 & 1.39 & 0.018 & \\
\hline & $\mathrm{Cr}$ & $37+$ & 6.1 & 0.52 & 3.33 & - & 0.03 & 0.04 & 1.80 & 0.017 & \\
\hline \multirow[t]{3}{*}{6} & $\mathrm{O}$ & $0-4$ & 6.6 & 0.00 & 24.81 & - & 0.06 & 0.08 & 2.82 & 0.022 & 13.8 \\
\hline & $\mathrm{A}$ & $4-28$ & 6.5 & 0.13 & 13.25 & 0.76 & 0.04 & 0.04 & 2.00 & 0.018 & \\
\hline & $\mathrm{C}$ & $28+$ & 5.4 & 0.27 & 4.47 & - & 0.04 & 0.04 & 1.80 & 0.020 & \\
\hline \multirow[t]{3}{*}{7} & $\mathrm{O}$ & $0-7$ & 6.0 & 0.00 & 8.24 & - & 0.07 & 0.08 & 3.43 & 0.019 & 4.50 \\
\hline & $\mathrm{A}$ & $7-9$ & 6.9 & 0.00 & 9.46 & 0.68 & 0.03 & 0.04 & 1.90 & 0.017 & \\
\hline & $\bar{C}$ & $9+$ & 7.4 & 0.09 & 3.89 & - & 0.04 & 0.04 & 1.90 & 0.019 & \\
\hline 8 & $\mathrm{C}$ & $0-5$ & 6.7 & 0.52 & 3.24 & - & 0.05 & 0.05 & 2.31 & 0.020 & 80.0 \\
\hline \multirow[t]{2}{*}{9} & $\mathrm{O}$ & $0-3$ & 6.0 & 0.00 & 8.80 & 0.57 & 0.07 & 0.07 & 3.33 & 0.021 & 22.4 \\
\hline & $\mathrm{AC}$ & 3 & 6.7 & 0.36 & 3.75 & - & 0.04 & 0.04 & 2.10 & 0.019 & \\
\hline \multirow[t]{2}{*}{10} & $\mathrm{~A}$ & $0-18$ & 6.5 & 0.04 & 12.6 & 0.62 & 0.02 & 0.11 & 4.67 & 0.005 & 22.4 \\
\hline & $\mathrm{C}$ & $18+$ & 6.5 & 0.07 & 12.5 & - & 0.04 & 0.08 & 3.73 & 0.010 & \\
\hline \multirow[t]{2}{*}{11} & $\mathrm{AC}$ & $0-3$ & 6.0 & 0.91 & 16.0 & - & 0.03 & 0.08 & 3.62 & 0.009 & 80.0 \\
\hline & $\mathrm{C}$ & $3+$ & 6.3 & 1.03 & 15.6 & - & 0.02 & 0.09 & 3.83 & 0.005 & \\
\hline \multirow[t]{2}{*}{12} & $\mathrm{~A}$ & $0-25$ & 6.2 & 0.23 & 17.7 & 0.80 & 0.02 & 0.1 & 4.25 & 0.005 & 30.0 \\
\hline & $\mathrm{C}$ & $25+$ & 6.1 & 0.22 & 10.0 & - & 0,02 & 0.07 & 3.10 & 0.006 & \\
\hline
\end{tabular}

\section{Vegetation cover}

In total, we detected 136 species of higher plants belonging to 106 genera, 49 families, 45 orders, 5 classes, and 4 divisions (Fig. 4). The families with the most species were Fabaceae and Poaceae, including 13 species (about 10\% of the identified diversity) and Asteraceae and Rosaceae (11 species, $8 \%$ of the identified diversity). A large number Fabacaea family members is a characteristic feature of disturbed habitats, while the Asteraceae and
Rosaceae families are the leading flora families of the Leningrad region. We detected 24 single-species families. The relatively high species richness of the family Orchidaceae (9 species, $6 \%$ of the total species list) is noteworthy, which is associated with the carbonate substrate of the quarry. We also recorded 22 species of mosses from 10 families, 11 epilithic lichens of 7 families, about 75 species of algae, and cyanoprokaryote species from 38 genera and 29 families. We detected representatives of all of the plant 


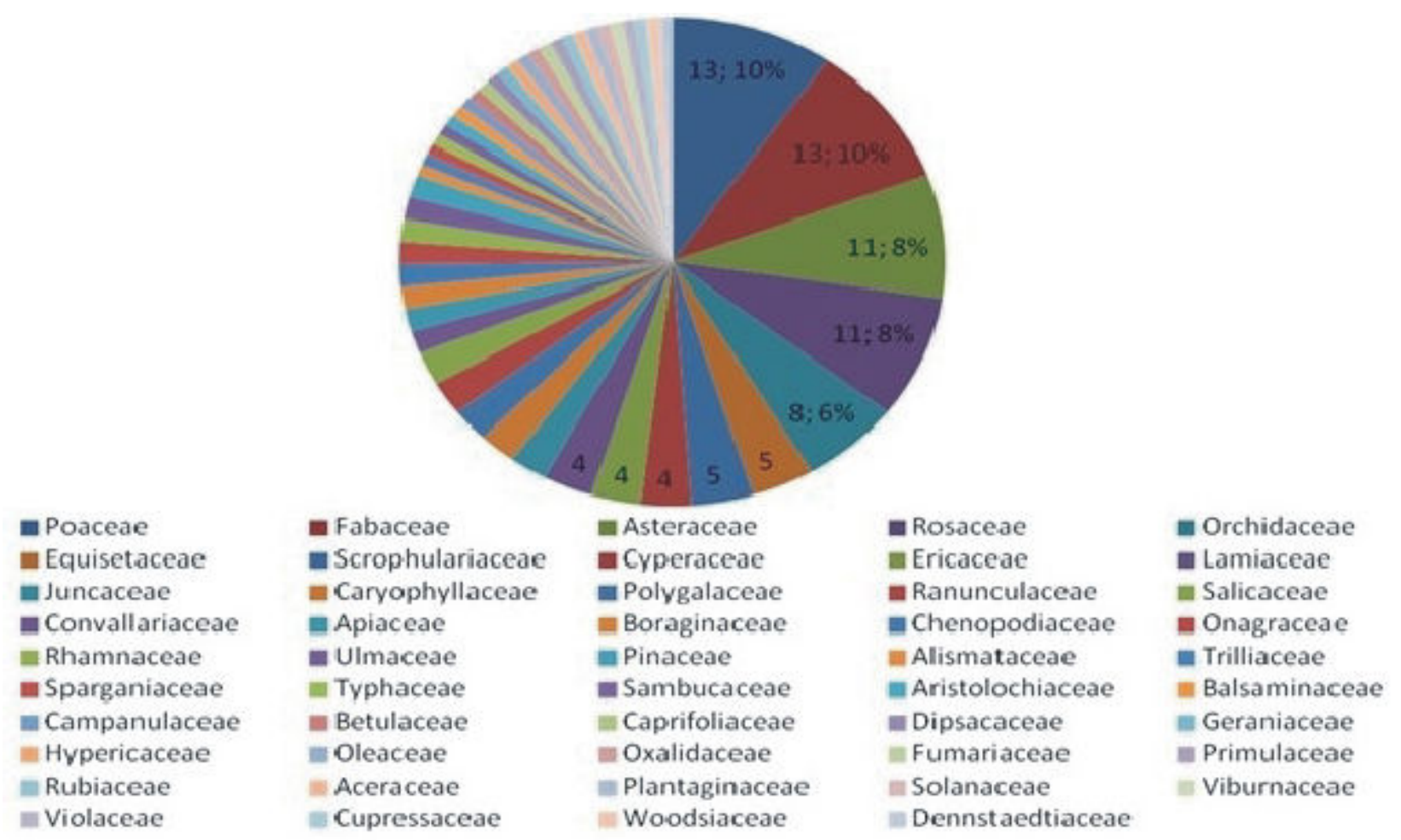

FIGURE 4. Species richness plant families

forms common to the Leningrad region (according to Cvelev (Cvelev 2000)).

According to the soil wealth exactingness approach, all environmental groups are presented (from oligotrophs to eutrophic and typical nitrophilic). Also, calcicole species are widespread in the quarry. The wide spectrum of soil water regimes (from xerophytes to hygrophytes) was represented at the quarry. The number of species of vascular plants in the areas ranged from 14 to 39 , depending on the ecotope. Fourteen protected species were detected among the various ecotopes of the quarry (Table 2).

The maximal similarity of species was observed on the rocky bottoms of the quarry $(92 \%)$. These areas have the most severe conditions, and only a few species can develop here (Table 3). The lowest number of common species are related to the areas occupying different positions in the relief (Site 4rt and 5th, and

TABLE 2. The list of protected species found in the "Pechurki" quarry

\begin{tabular}{|c|c|c|c|c|c|}
\hline Division & Class & Order & Family & Genius & Type \\
\hline Equisetophyta & Equisetopsida & Equisetales & Equisetaceae & Equisetum & $\begin{array}{l}\text { Equisetum variegatum Schleich. ex Weber \& D. } \\
\text { Mohr }\end{array}$ \\
\hline \multirow[t]{13}{*}{ Magnoliophyta } & Liliopsida & Orchidales & Orchidaceae & Cypripedium & Cypripedium calceolu $\mathrm{L}$. \\
\hline & & & & Dactylorhiza & Dactylorhiza fuchsii (Druce) Soo \\
\hline & & & & & Dactylorhiza incarnata (L.) Soo \\
\hline & & & & & Dactylorhiza maculata (L.) Soo \\
\hline & & & & Epipactis & Epipactis atrorubens (Hoffm.) Besser \\
\hline & & & & & Epipactis helleborine (L.) Crantz \\
\hline & & & & & Epipactis palustris (L.) Crantz \\
\hline & & & & Gymnadenia & Gymnadenia conopsea (L.) R. Br. \\
\hline & & & & Platanthera & Platanthera bifolia (L.) Rich. \\
\hline & Magnoliopsida & Ericales & Ericaceae & Chimaphila & Chimaphila umbellata (L.) W.P.C. Barton \\
\hline & & Fabales & Fabaceae & Anthyllis & Anthyllis vulneraria \\
\hline & & & & Vicia & Vicia hirsuta (L.) Gray \\
\hline & & Polygalales & Polygalaceae & Polygala & Polygala amarella Crantz \\
\hline
\end{tabular}


TABLE 3. The similarity of species composition of different parts of the quarry (Sorensen-Czekanowski coefficient)

\begin{tabular}{llllllllllll}
\hline $\begin{array}{l}\text { Site/ } \\
\text { Site }\end{array}$ & 2 & 3 & 4 & 5 & 6 & 7 & 8 & 9 & 10 & 11 & 12 \\
\hline 1 & 53 & 39 & 24 & 13 & 13 & 29 & 38 & 46 & 66 & 43 & 49 \\
\hline 2 & & 29 & 24 & 18 & 11 & 31 & 44 & 32 & 45 & 48 & 42 \\
\hline 3 & & & 37 & 17 & 4 & 15 & 22 & 28 & 26 & 27 & 36 \\
\hline 4 & & & & 4 & 14 & 10 & 20 & 31 & 30 & 21 & 28 \\
\hline 5 & & & & 30 & 29 & 13 & 20 & 10 & 19 & 18 \\
\hline 6 & & & & & & 22 & 13 & 8 & 16 & 14 & 48 \\
\hline 7 & & & & & & 44 & 40 & 37 & 37 & 31 \\
\hline 8 & & & & & & & & 26 & 41 & 92 & 47 \\
\hline 9 & & & & & & & & & 61 & 27 & 32 \\
\hline 10 & & & & & & & & & 42 & 40 \\
\hline 11 & & & & & & & & & & 48 \\
\hline
\end{tabular}

3 rd and 6 th are only $4 \%$ of the total of willows). Communities of $3 \mathrm{rd}$ and $4 \mathrm{rt}$ position occupied eluvial positions in relief, and 5 and 6 - accumulative positions. Thus, there are completely different physicochemical soil parameters.

\section{Diversity of plants at the eluvial ecotopes}

The eluvial ecotopes (sites 1, 3, 4, 12) of the quarry differ in their physical and chemical parameters. Because of this, even within the same type of relief, diverse communities are formed. For each ecotope, the number of selected plant species varied from 19 to 31. Small-leaved forests with a predominance of Populus tremula and Betula pendula were most typical for dumps of late succession stages. In such cases, the grass-shrub cover is mainly edge-meadow and meadow species (e.g., Poa pratensis and Calamagrostis epigeios). Furthermore, for coniferous forests of Pinus sylvestris and Picea abies, the herb-shrub floor mainly consists of forest-edge and forest species (e.g., Convallaria majalis and Pyrola rotundifolia). Mixed forests with indistinct dominants were rarely detected. The tops of the dumps, regardless of the length of overgrowth, tended to differ in species composition, the proportion of common species varied from 24 to $39 \%$. On those dumps that are not overgrowing over 12 years, currently, shrub cover with the dominance of Rubus idaeus is forming. On the eluvial ecotopes of the quarry, we detected eight species of higher plants (Chimaphila umbellate, Dactylorhiza fushsii, D. maculata, Epipactis atrorubens, E. palustris, Equisetum variegatum, Gymnadenia conopsea, and Cypripedium calceolus) that are protected in the Leningrad region.

\section{Diversity of plants at the transit-trans eluvial ecotopes}

Transit-transeluvial ecotopes $(7,9,10)$ are widespread in the quarry and include different exposition slopes of dumps and stepped walls of the quarry. Currently, the bare steeped slopes are completely covered with vegetation. Species composition of the dump slopes coincides with the species diversity top of the piles. Beyond the slopes, the terraced areas of the quarry are represented by transeluvial ecotopes. Mining and biological reclamation have been performed on such sites and, over the years, pine has been planted here. Currently, these sites differ in their period of overgrowth, soil texture class and moisture conditions. As a result, on the quarry green mosses and grass associations are represented, pine and lichen formed on a well-drained, sandy area. For these areas, species diversity is not a useful indicator since each represents a different type of forest. Thus, these areas are useful for preserving biodiversity. It should be noted that Chimaphila umbellate is fixed and this species is known as vulnerable. In the bright, dry forests of the quarry, Dactylorhiza maculate and Epipactis helleborine were found growing. The well-moistened and sometimes swampy areas were often inhabited by protected species, such as Dactylorhiza baltica, Epipactis palustris, and Equisetum variegatum. These species from Red data book list should be protected despite the specificity of ecotope.

\section{Diversity of plants at the self-overgrown bottoms}

Self-overgrown bottoms (sites 8 and 11) of the quarry characterizes by high stones content $(80 \%)$, surface overcompaction and low water-holding capacity. Overgrowing by higher vegetation is slow; the first colonists inhabit nano-lowerings since in this conditions there is some accumulation of fine earth, seeds, slightly better moisture conditions. On the rocks, a large number of epilithic lichens were detected, including Arthonia fusca, Acarospora moenium, A. glaucocarpa, Candelariella aurella, Lecanora dispersa, L. crenulata, Lecidella stigmatea, Phaeophyscia nigricans, Hymenelia epulotica, Sarcogyne regularis, and Verrucaria sp. The total projective cover of vegetation in these areas reaches $25 \%$, and the main dominants here are Ceratodon purputreus and Bryum pseudotriquetum. The number of species of vascular plants in the self-overgrown bottoms has remained stable over the time (19-20 species detected at all such sites of differing ages). 
The species composition of the bottom part of the quarry is uniform (Sërensona-Czekanowski coefficient of $92 \%$ ). Vegetation is growing according the forest trend; the most characteristic species are Pinus sylvestris, Picea abies, and Betula pendula. In the depressions, Salix sarrea has developed. Herbaceous vegetation is represented by individual parcels, some of which are typical weed species (Tussilago farfara), and representatives of the edge-forestry and edge-meadow (Fragaria vesca, Solidago virgaurea, Calamagrostis epigeios, Stellaria graminea, and Agrostis tenuis). In these areas, we detected five endangered species (Dactylohiza incarnata, D. maculata, Gymnadenia conopsea, Epipactis atrorubens, and Epipactis palustris) from the Orchid family, which is under protection in the Leningrad region.

\section{Diversity of plants at the quarry}

The lowest diversity was at Site 10 , where, on a flat surface, pine seedlings were planted in 1970 (Table 4). The greatest diversity, according to the Shannon index, was at the recently remediated site, where crown closure has not yet occurred, and typical forest species have not yet been supplanted by edge-meadow species. According to the Simpson index, Site 12 has the greatest diversity; this site was a quarry dump where spontaneous succession without human intervention has been ongoing for at least 30 years. On flat areas, biodiversity decreased under biological reclamation. In areas where development was by spontaneous succession (e.g., dumps), the level of biodiversity has increased. Interestingly, on strongly rocky areas (dumps of large fragments and rocky bottoms) development is so slow that no significant changes have occurred over a 46 year period. This is because the time has been insufficient for natural algae conversion of the substrate. Thus, if the aim is to maximize biodiversity, the creation of favorable substrate conditions and the abandoning land for self-overgrowing is the best method for remediation of carbonate quarries. This approach is also the most economically advantageous.

\section{Relationships between plant communities and environmental variables}

Five environmental factors (texture class of the soil, stoniness, content of physical clay (clay content $<0,001 \mathrm{~mm}$ ), $\mathrm{pH}$ in water, and moisture) were selected for inclusion in the model (Table 5). These five factors have the greatest impact on the distribution of vegetation.

TABLE 5. Significant variables selected by direct selection

\begin{tabular}{llrl}
\hline $\begin{array}{l}\text { Significant } \\
\text { variables }\end{array}$ & $\begin{array}{l}\text { Cumulative } \\
\text { adjusted R2 }\end{array}$ & $\mathrm{F}$ & $\mathrm{P}$ \\
\hline Soil texture & 0.035 & 11.2 & $<0.001$ \\
\hline $\begin{array}{l}\text { Content of physical clay } \\
\text { fractions }\end{array}$ & 0.050 & 5.3 & $<0.001$ \\
\hline Moisture & 0.098 & 3.9 & $<0.001$ \\
\hline pH in water & 0.105 & 2.5 & $<0.002$ \\
\hline Stoniness & 0.114 & 2.7 & $<0.003$ \\
\hline
\end{tabular}

Our canonical analysis results are shown in Figure 5. The first axis explains $65 \%$ of the variance and the second axis explains $23 \%$. Areas with maximum stoniness are mostly colonized by sparse vegetation with a predominance of Ceratodon purpureus and Bryum pseudotriquetrum. Bryophytes and lichens are dominant in rocky areas (dumps of large fragments and rocky bottoms - sites 8 and 11) because they are better adapted to these harsh conditions than vascular plants are (Glime 2007).

Areas with a clay portion $37,5 \pm 3 \%$ are colonized by spruce grove. Drained sandy areas are occupied by various types of pine. Small-leaved forests are dominant in areas with a large amount of skeletal material and relatively low content of fine earth.

\section{Soil microbiome}

By principal component analysis (PCA), the age of dumps was identified as the most significant environmental factor (explaining $19.9 \%$ of the total variance) (Fig. 6). The microbial communities of the

TABLE 4. Indices of biodiversity for different sections of the quarry

\begin{tabular}{|c|c|c|c|c|c|c|c|c|c|c|c|c|}
\hline \multicolumn{12}{|c|}{ Site number } & \multirow[t]{2}{*}{ Indices } \\
\hline 1 & 2 & 3 & 4 & 5 & 6 & 7 & 8 & 9 & 10 & 11 & 12 & \\
\hline 2.41 & 3.13 & 2.29 & 2.21 & 2.83 & 2.98 & 3.37 & 2.91 & 2.99 & 2.10 & 2.83 & 3.31 & Shannon \\
\hline 6.94 & 21.7 & 5.59 & 5.92 & 16.0 & 20.7 & 24.5 & 25.7 & 17.0 & 5.34 & 26.3 & 33.4 & Reverse index of Simpson \\
\hline
\end{tabular}




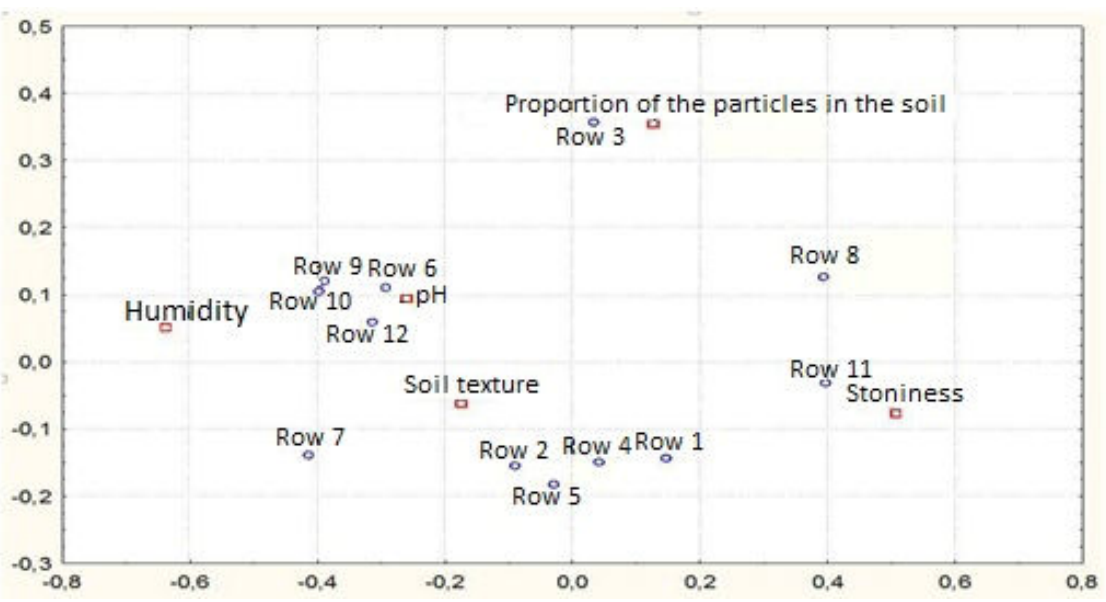

FIGURE 5. Canonical correspondence analysis. Blue circles - plant communities; red squares environmental factors

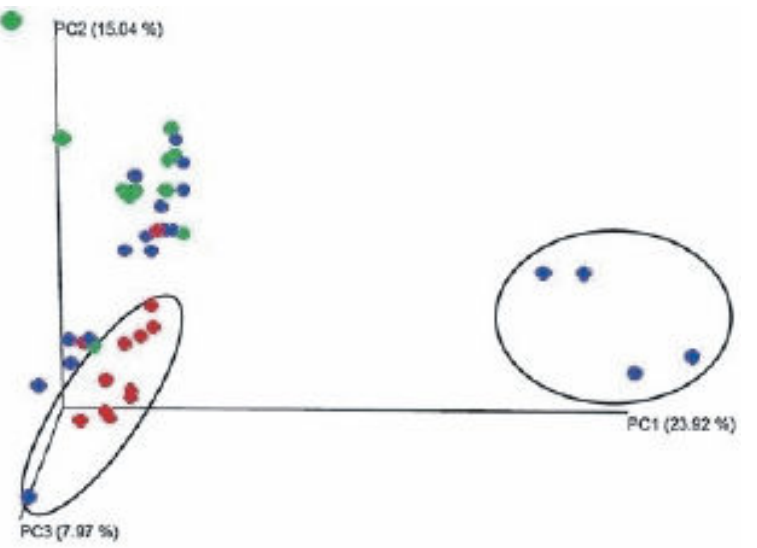

FIGURE 6. Principal component analysis. Red circles - old dumps (35 years), blue circles - middle-aged dumps ( $28-30$ years), green circles - young dumps ( $8-16$ years)

old ( $\geq 35$-years-old) dumps are clearly isolated, communities of microorganisms of young (8-16years-old) and middle-aged (28-30-years-old) dumps tend to group into separate clusters. Taxonomic analysis of communities at the phyla level did not reveal differences between differently aged dumps. In all cases, the largest phyla were the Proteobacteria (55.7\%), Actinobacteria (17.0\%), Bacteroidetes (10.3\%), Acidobacteria (6.4\%), and Chloroflexi (3.8\%). The dominant taxa in young dumps were Acinetobacter ( $8.8 \%$ of the total community), Micrococcaceae (8\%) and Pseudomonas (6\%). In the middle-aged dumps, representatives of Micrococcaceae (4.5\%) and Sphingomonadaceae (1.4\%) prevailed (Fig. 7). Old dumps showed a high proportion of representatives of Bradyrhizobiaceae (5\%), Chitinophagaceae $(2.9 \%)$ and Hyphomicrobiaceae $(2.5 \%)$. Compared to young and middle-aged dumps, old dumps are characterized by a significant (6-8 times) increase in representatives of Micromonosporaceae and Sinobacteraceae. Communities of young dumps have more representatives of Pseudomonas (4.2-times) and Micrococcaceae (3.8-times) than the communities of old dumps (Fig. 8). The communities of wet terraces (sites $5,6,7$ ) also differ from the microbiomes of the remaining ecotopes. However, no significant differences could be identified in $\mathrm{pH}$ values, which is an important soil characteristic, had no significant effect on the composition of the microbial community.

\section{DISCUSSION}

The main processes of transformation of the mineral soil are chemical-, biochemical-, and physical weathering and alteration of the carbonate rocks. Intensive weathering of the limestone debris contributes to a significant content of fine earth (the only exception is the rocky bottom of the quarry), which, in turn, increases the moisture content and fertility. Our research results showed, that organic matter accumulation and acidification in the soil horizons were the main pedogenetic processes in all of the soils. These processes led to the formation of A horizons, with a maximum thickness and highest organic carbon content in accumulative ecotype with optimal moisture conditions and physical parameters of the substrate. The differences between the superficial and subsurface horizons decreased with increasing overgrowing time; this is because of more intensive organic matter incorporation in the soil profile. Together with the increase in organic matter accumulation, acidification and carbonate leaching proceeded fast enough, particularly in topsoil horizons layer. Under small-leaved forests, soil-forming processes and horizon formation were similar for accumulative ecotypes, but faster compared to those observed on eluvial ecotypes.

Most of the environmental factors are considered as optimal for the development of vegetation. The exception was the high density and over-compacted substrates on the stony bottoms of the quarry; these properties are obstacles for the development of plant 
FIGURE 7. Taxonomic structure of microbioms at the level of bacterial families (families representing more than $0.5 \%$ in the community are represented and the share of which is statistically significantly different between dumps of different ages)

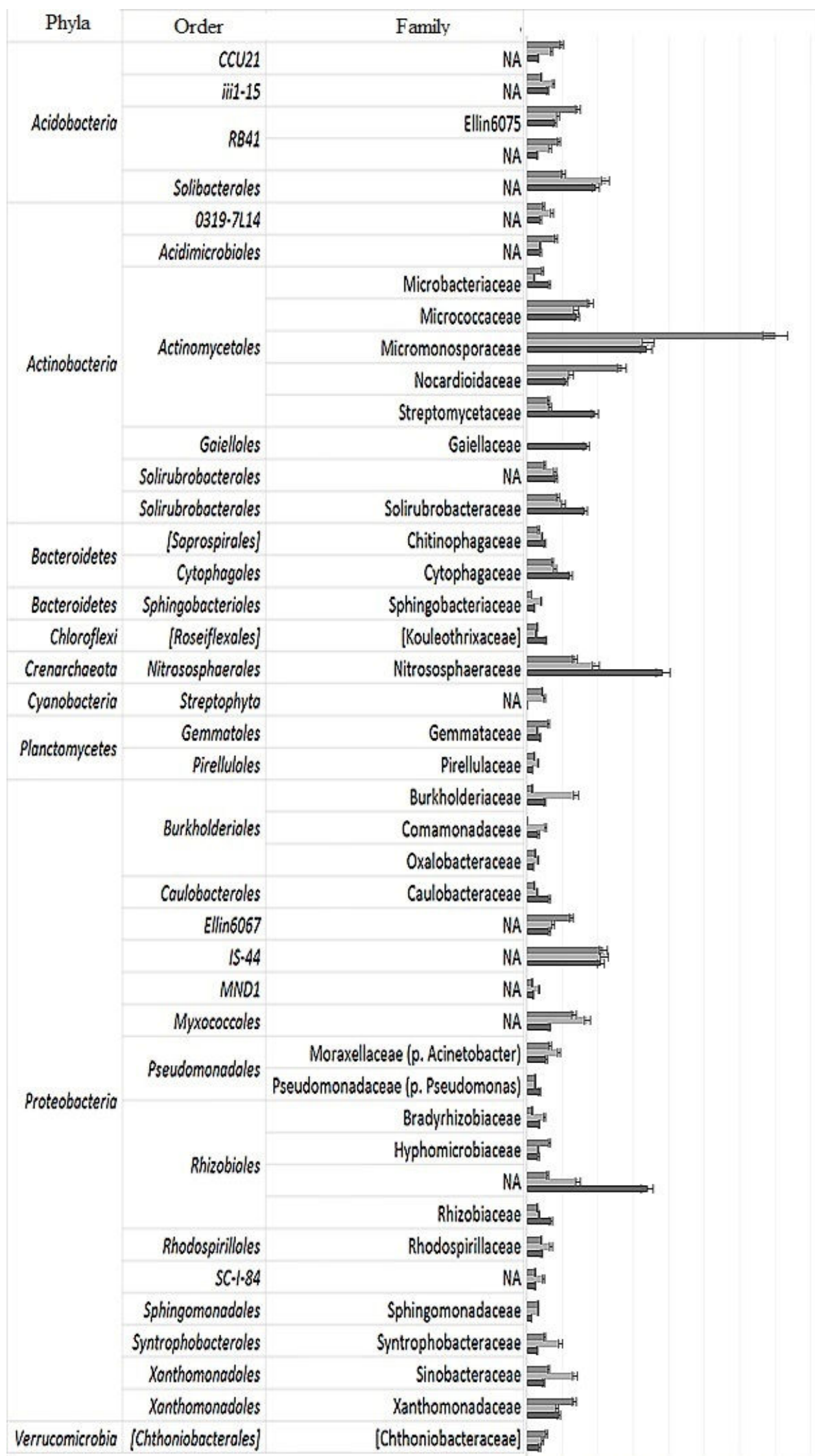

$\begin{array}{lllllllll}0,00 & 0,02 & 0,04 & 0,06 & 0,08 & 0,10 & 0,12 & 0,14 & 0,16\end{array}$ 


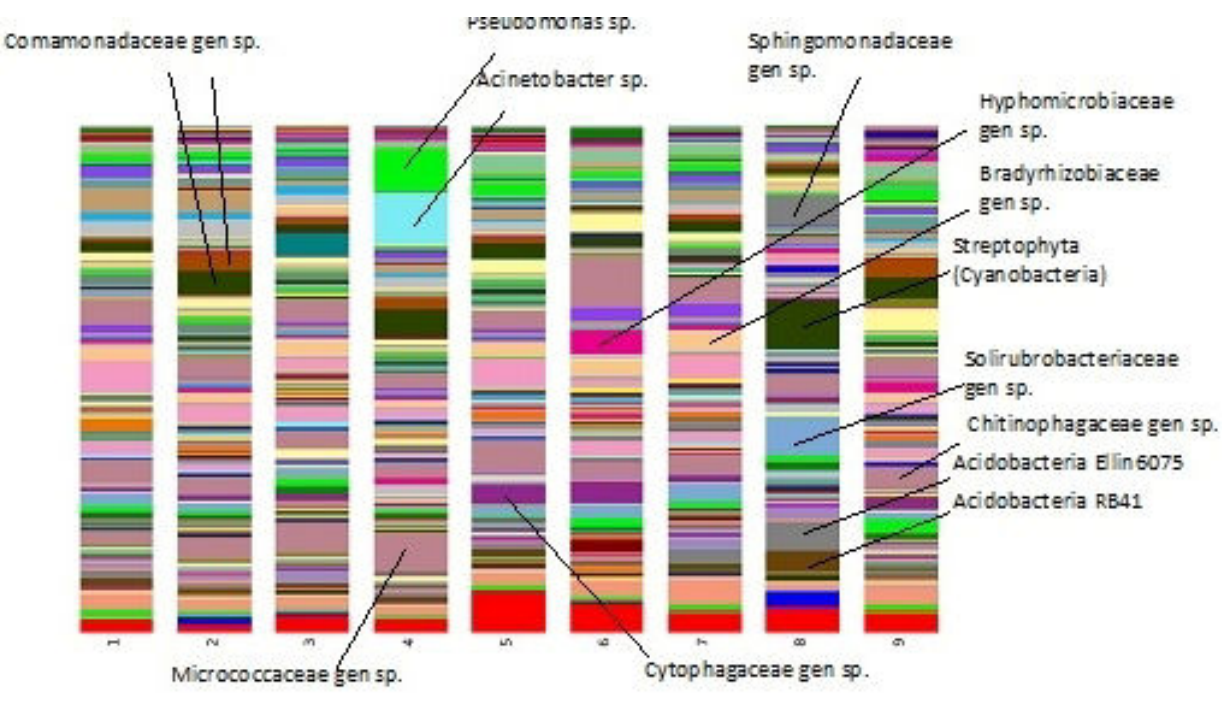

FIGURE 8. Taxonomic structure of microbioms at the level of bacterial genus (1-28 years old, dump. Sparse vegetation $\mathrm{pH} 4.4$; $2-16$ years old, dry terrace. Small pine, $\mathrm{pH} 6.3 ; 3-30$ years old, heap. Rare vegetation $\mathrm{pH} 5.8 ; 4-8$ years old, dump. Sparse vegetation pH 5.2; 5-35 years old, wet terrace. Small-leaved forest, $\mathrm{pH} 5.7 ; 6-35$ years old, wet terrace. Small-leaved forest, $\mathrm{pH} 6.5 ; 7-35$ years old, wet terrace. Greenwood pine forest, $\mathrm{pH} 7.4 ; 8-29$ years, dump. Sparse vegetation, $\mathrm{pH}$ 6.7; 9-29 years old, dry terrace. Sparse vegetation, $\mathrm{pH} 6.8$ ).

communities. Also, results of the microbial metabolic rate indicate a reduced stability of microbial communities and the inefficient use of the organic substrate, especially during the early stages of overgrowing.

Our results are consistent with multiple studies of quarries under various environmental conditions and geographical zones have shown that abandoned quarries can enhance biodiversity by acting as refuges for plant and animal species (Jefferson 1984; Benes et al. 2003). Landform diversity induced by mining activity provides a diversity of ecological niches suitable to a large number of plant and animal species, including species with high heritage value. Thus, abandoned quarries could be viewed as tools for providing a variety of potential niches for various groups of organisms (Burnett et al. 1998).

According to Frouz and Nováková (2005), who studied the microbiological state of various quarries in the Czech Republic, the index of soil respiration per unit of microbial biomass decreases with increasing period of overgrowing. However, according to our data, it is difficult to identify the trend of changes in microbiological indicators with age. Also, the authors note that under 30-40 years of community, most microbiological indicators are the same as in undisturbed communities. To such conclusions came Malyuta et al. (2015); their results prove that the level of active microbial biomass in the soils of the sand pit is slightly different from undisturbed soils, however, it should be noted that our methods of assessment differ. According to our research, a very low level of intensity of microbiological processes, regardless of the type of substrate, plant community and the period of overgrowth, is found on a quarry.

An analysis of the taxonomic structure showed the formation of microbial communities in the study areas characteristic of acidified Podzols and Calcaric Leptosols of the Northwest (Chirak et al. 2013). A significant proportion of bacterial communities belonging to the copiotrophic forms indicate that no climax stage of succession has been achieved in any of the sites. The presence of a large number of oligotrophs indicating the completeness of the carbon cycle and the stabilization of the composition of the microbial community (Leff and Fierer 2013) can be an indicator of the pre-climax stage of the oldest sites (from 35 years). Alfa-diversity at all sites is quite low, this may be a consequence of the low intensity of soil formation, the values are well correlated with those for Podzols and Calcaric Leptosols of the North-West region, investigated earlier (Chirak et al., 2013). Our results contradict the generally accepted opinion that the composition of microbial communities is most affected by the $\mathrm{pH}$ and soil moisture response (Chirak et al., 2013). The greatest influence is rendered by the time of overgrowing of the site, it needs to be clarified that time is a complex of environmental factors.

\section{CONCLUSIONS}

In this study, we characterized the main types of ecotypes of the Pechurki quarry, western Russia. Special attention was given to the main pedogenic processes under different vegetation covers. In total, 
136 species of higher plants were recorded, of which 14 were classified as threatened. We found high heterogeneity and diversity of soils. Soil texture, clay content, moisture, $\mathrm{pH}$ in water, and content of rock fragments $>2 \mathrm{~mm}$ had the greatest influence on the natural colonization of this limestone quarry. We suggest that a relatively fast rate of soil formation can occur when the substrate parameters are favorable, which leads to rapid plant community succession. On flat areas, biodiversity is reduced under biological reclamation, whereas biodiversity increases in those areas where development takes place according to the type of spontaneous succession. Based on our findings and an analysis of the literature, we propose that a significant part of quarries can be successfully rehabilitated by self-over revegetation. We also recommend saving complicated relief on the quarry, which positively affects the biodiversity level. Our data shows that, for sites with numerous ecological limitations (e.g., over-compacted substrate and high content of rock fragments $>2 \mathrm{~mm}$ ), reclamation is necessary. For example, these sites should be covered by a top layer of soft overburden to the rock bottoms, thereby improving the physical properties of the substrate, thus encouraging the overgrowing process. An important opportunity for increasing the speed of succession and maintaining the stability of ecosystems is an increase the proportion of microorganisms belonging to oligotrophs in the early stages of overgrowing.

\section{ACKNOWLEDGMENTS}

This study was supported by the following grants: Russian Science Foundation, project No.17-16-01030 "Soil biota dynamics in chronoseries of posttechnogenic landscapes: analyses of soil-ecological effectiveness of ecosystems restoration and Slantsy cement plant 'Cesla' (HeidelbergCement Group).

\section{REFERENCES}

Abakumov E.V., Cajthaml T., Brus J., Frouz J., 2013. Humus accumulation, humification, and humic acid composition in soils of two post-mining chronosequences after coal mining Journal of Soils and Sediments 13(3): 491-500.

Abakumov E.V., Suyundokov Ya.T., Pigareva T.A., Semenova I.N., Khasanova R.F., Biktimerova G.Ya., Rafikova Yu.S., Ilbulova G.R., 2016. Biological and sanitary evaluation of Sibaisky quarry dumps of the Bashkortostan Republic. Gigiena i Sanitariya 95(10): 929-934.

Abakumov E.V., Suyundukov Ya.T., Biktimerova G.Ya., Pigareva T.A., 2015. Ecological and sanitary characteristics of the copper pyrite quarry (Baymak Region, The Republic of Bashkortostan). Gigiena i Sanitariya 94 (6): 46-50.
Acosta-Martinez V., Dowd S.E., Sun Y., Wester D., Allen V., 2010. Pyrosequencing analysis for characterization of soil bacterial populations as affected by an integrated livestock-cotton production system. Applied Soil Ecology 45(1): 13-25 (doi: 10.1016/j.apsoil.2010.01.005).

Ananyeva N.D., Susyan E.A., Chernova O.V., Wirth S., 2008. Microbial respiration activities of soils from different climatic regions of European Russia. European Journal of Soil Biology 44(2): 147-157.

Anderson J.P.E., Domsch K.H.A. 1978. Phisiological method for the quantitative measurement of microbial biomass in soils. Soil Biology and Biochemistry 10(3): 215-221.

Androhanov V.A., Ovsyannikova S.V., Kurachev V.M., 2000. Tekhnozemy: svojstva, rezhimy, funkcionirovanie. Novosibirsk. 202 pp. (in Russian).

Archegova I.B., 2013. Zakonomernosti formirovaniya bioraznoobraziya rastitel'nyh soobshchestv v vosstanavlivayushchihsya i preobrazuyushchihsya ehkosistemah v raznyh tipah tekhnogennyh ob"ektov na Severo-Vostoke Evropejskoj chasti Rossii. Vestnik instituta biologii Komi nauchnogo centra Ural'skogo otdeleniya RAN 3(179): 24-27 (in Russian).

Bates S.T., Berg-Lyons D., Caporaso J.G., Walters W.A., Knight R., Fierer N., 2010. Examining the global distribution of dominant archaeal populations in soil. ISME Journal 5: 908917.

Benes J., Kepka P. \& Konvicka M., 2003. Limestone quarries as refuges for European xerophilous butterflies. Conservation Biology 17: 1058-1069.

Berger J.J., 1993. Ecological restoration and nonindigenous plant species: a review. Restoration Ecology 1: 74-82.

Bishop S.C. and Chapin F.S., 1989. Patterns of natural revegetation on abandoned gravel pads in arctic Alaska. Journal of Applied Ecology 26(3): 1073-1081.

Brown C.S. and Rice K.J., 2000. The mark of zorro: Effects of the exotic annual grass Vulpia myuros on California native perennial grasses. Restoration Ecology 8(1): 10-17.

Burga C.A., Krüsi B., Egli M., Wernli M., Elsener S., Ziefle M., Fischer T., Mavris C., 2010. Plant succession and soil development on the foreland of the Morteratsch glacier (Pontresina, Switzerland): straight forward or chaotic? Flora 205: 561576.

Burnett MR, August PV, Brown JH, Killingbeck KT., 1998. The influence of geomorphological heterogeneity on biodiversity. I. A patch-scale perspective. Conservation Biology 12: 363370.

Burns R.G., DeForest J.L., Marxsen J., Sinsabaugh R.L., Stromberger M.E., Wallenstein M.D., Weintraub M.N., Zoppini A., 2013. Soil enzymes in a changing environment: current knowledge and future directions. Soil Biology and Biochemistry 58: 216-234 (doi: 10.1016/j.soilbio.2012.11.009).

Caporaso J.G., Kuczynski J., Stombaugh J., Bittinger K., Bushman F.D., Costello E.K., Fierer N., Peńa A.G., Goodrich J.K., Gordon J.I., Huttley G.A., Kelley S.T., Knights D., Koenig J.E., Ley R.E., Lozupone C.A., McDonald D., Muegge B.D., Pirrung M., Reeder J., Sevinsky J.R., Turnbaugh P.J., Walters W.A., Widmann J., Yatsunenko T., Zaneveld J., Knight R., 2010. QIIME allows analysis of high- throughput community sequencing data Intensity normalization improves color calling in SOLiD sequencing. Nature Publishing Grour, Nature methods 7: 335-336. 
Chirak E.L., Pershina E.V., Dol'nik A.S., Kutovaya O.V., Vasilenko E.S., Kogut B.M., Merzlyakova Ya.V., Andronov E.E., 2013. Taksonomicheskaya struktura mikrobnyh soobshchestv v pochvah razlichnyh tipov po dannym vysokoproizvoditel'nogo sekvenirovaniya bibliotek gena 16S-rRNK. Selskohozyajstvennaya biologia rastenij 3: 100-109 (in Russian).

Cvelev N.N., 2000. Opredelitel sosudistyh rastenij Severo-Zapadnoj Rossii (Leningradskaya Pskovskaya i Novgorodskaya oblasti). Izdatelstvo Himiko-farmacevticheskoj akademii, Sankt Petersburg, Russia: 789 pp. (in Russian).

Dangi S.R., Stahl P.D., Wick A.F., Ingram L.J., Buyer J.S., 2012. Soil microbial community recovery in reclaimed soils on a surface coal mine site. Soil Science Society of America Journal 76(3): 915-924 (doi: 10.2136/sssaj2011.0288).

Densmore R.V., 1992. Succession on an alaskan tundra disturbance with and without assisted revegetation with grass. Arctic and Alpine Research 24(3): 238-243.

DeSantis T.Z., Hugenholtz P., Larsen N., Rojas M., Brodie E.L., Keller K., Huber T., Dalevi D., Hu P., Andersen G.L., 2006. Greengenes, a chimera-checked 16S rRNA gene database and workbench compatible with ARB. Applied Environmental Microbiology 72: 5069-5072.

Dmitrakova Y.A., Abakumov E.V., 2018a. Restoration of Soils and Vegetation on Reclamation Sites of the Kingisepp Phosphorite Field. Eurasian Soil Science 51 (5): 588-597.

Dmitrakova Y.A., Abakumov E.V., Pershina E.A., Ivanova E.A., Andronov E.E., 2018b. Dynamics of the plant community and microbiom of chrono-series of post-technological soil in limestone quarry in the conditions of recultivation. Sel'skokhozyaistvennaya Biologiya 53 (3): 557-569 (in Russian).

El-Fadel M., Zeinati M., \& Jamali D., 2000. Water Resources in Lebanon: Characterization, Water Balance and Constraints. International Journal of Water Resources Development 16(4): 615-638.

Fierer N., Leff J.W., Adams B.J., Nielsen U.N., Bates S.T., Lauber C.L., Owens S., Gilberte J.A., Wall D.H., Caporaso J.G., 2012. Cross-biome metagenomic analyses of soil microbial communities and their functional attributes. PNAS USA, 109(52): 21390-21395 (doi: 10.1073/pnas.1215210110).

Frouz J., Nováková A., 2005. Development of soil microbial properties in topsoil layer during spontaneous succession in heaps after brown coal mining in relation to humus microstructure development. Geoderma 129: 54-64.

Glime J., 2007. Bryophyte ecology. Physiological ecology (ebook).

Johnson S., 2006. Good Practice Guidance for Mining and Biodiversity, International Council on Mining and Metals (ICMM), London, United Kingdom: 142 pp.

Gretarsdottir J., Aradottir A.L., Vandvik V., Heegaard E., Birks H.J.B., 2004. Long-term effects of reclamation treatments on plant succession in Iceland. Restoration Ecology 12(2): 268278 (doi: 567 10.1111/j.1061-2971.2004.00371.x).

Ivlev V.V., 1994. Vsevolozhskij rajon Leningradskoj Oblasti Istoriko-geograficheskij spravochnik. Petropol, Sankt Petersburg, Russia: 156 pp. (in Russian).

IUSS Working Group WRB., 2015. World Reference Base for Soil Resources 2014, update 2015 International soil classification system for naming soils and creating legends for soil maps. World Soil Resources Reports No. 106. FAO, Rome.
Jefferson R.G., 1984. Quarries and wildlife conservation in the Yorkshire Wolds, England Biological Conservation 29: 363380.

Jomaa I., Auda Y., Abi Saleh B., Hamze M., Safi S., 2008. Landscape spatialdynamics over 38 years under natural and anthropogenic pressures in Mount Lebanon Landscape and Urban Planning 87: 67-75.

Khater C., Martin A. and Maillet J. 2003. Spontaneous vegetation dynamics and restoration prospects for limestone quarries in Lebanon. Applied Vegetation Science 6: 199-204.

Kopceva E.M., 2005. Estestvennoe vosstanovlenie rastitel'nosti na tekhnogennyh mestoobitaniyah Krajnego Severa: YAmal'skij sektor Arktiki. SPb: 235 pp. (in Russian).

Kurá• V., Frouz J., Kurá• M., Mako A., Shustr V., Cejpek J., Romanov O.V., Abakumov E.V., 2012. Changes in some physical properties of soils in the chronosequence of self-overgrown dumps of the Sokolov quarry-dump complex, Czechia. Eurasian Soil Science 45(3): 266-272.

Labbé L., Lanctôt B., Fortin J.A., 1995. Étalement des îlots d'aulnes et enrichis sement dessolsau complexe La Grande. Rapport pour la Vice-présidence Environnement, HydroQuébec. Institut de recherché en biologie végétale de Montréal Montréal, Qué.

Laitinen J., Rehell S., Oksanen J., 2008. Community and species responses to water level fluctuations with reference to soil layers in different habitats of mid-boreal mire complexes. Plant Ecology 194(1): 17-36 (doi: 10.1007/s11258-007-9271-3).

Leff J.W., Fierer N., 2013. Bacterial communities associated with the surfaces of fresh fruits and vegetables. PLOS ONE 8:e59310 (doi: 10.1371/journal.pone.0059310).

Li Y., Wen H., Chen L., Yin T., 2014. Succession of bacterial community structure and diversity in soil along a chronosequence of reclamation and re-vegetation on coal mine spoils in China. PLoS ONE, 9(12): e115024 (doi: 10.1371/journal.pone.0115024).

Liu S., Liu W., Yang M., Zhou L., Liang H. 2016. The genetic diversity of soil bacteria affected by phytoremediation in a typical barren rare earth mined site of South China. SpringerPlus 5(1): 1131 (doi: 10.1186/s40064-016-2814-0).

Lozupone C., Knight R., 2005. UniFrac: a New Phylogenetic Method for Comparing Microbial Communities. Applied Environmental Microbiology 71: 8228-8235.

Luna L., Pastorelli R., Bastida F., 2016. The combination of quarry restoration strategies in semiarid climate induces different responses in biochemical and microbiological soil properties. Applied Soil Ecology 107: 33-47 (doi: 10.1016/ j.apsoil.2016.05.006).

Malyuta O.V., Gordeeva T.H., Tuev A.S., Kurochkina M.A., 2015. Issledovanie stepeni antropogennoj narushennosti prirodnoj sredy v usloviyah peschanogo kar'era// Politematicheskij setevoj ehlektronnyj nauchnyj zhurnal Kubanskogo gosudarstvennogo agrarnogo universiteta 111: 886-896 (in Russian).

Mudd G.M., 2010. The Environmental Sustainability of Mining in Australia: Key Mega Trends and Looming Constraints. Resources Policy 35: 98-115.

Neshataev V.YU., Karapuhin N.S., Efremov D.F., Knol' V.V., Neshataev M.V., SHtak K.D., 2012. Prakticheskoe posobie po vosstanovleniyu rastitel'nogo pokrova na zemlyah, narushennyh otkrytymi gornymi razrabotkami pri osvoenii mestorozhdenij poleznyh iskopaemyh v usloviyah Kamchatskogo kraya. SPb: 159 pp. (in Russian). 
Ponomareva V., Plotnikova T.F., 1980. Humus and soil formation. Sankt Petersburg, Russia: 280 pp.

Prach K., 2003. Spontaneous succession in Central-European man-made habitats: what information can be used in restoration practice? Applied Vegetation Science 6: 125-129.

Prihodko V.E., Sizemskaya M.L., 2015. Bazalnoe dyhanie i sostav mikrobnoj biomassy celinnyh agro- i lesomeliorirovannyh polupustynnyh pochv severnogo Prikaspiya. Pochvovedenie 8: 974- 983 (in Russian).

Rastvorova O.G., 1983: Fizika pochv (prakticheskoe rukovodstvo), Sankt Petersburg, Russia: 191 pp. (in Russian).

Řehounková K., Č́žžek L., Řehounek J., Ňebelíková L., Tropek R., Lencová K., Bogusch P., Marhoul P., Máca J., 2016. Additional disturbances as a beneficial tool for restoration of postmining sites: a multi-taxa approach. Environmental Science and Pollution Research 23: 13745-13753.

Shaban A., El-Baz F., Khawlie M., 2007. The relation between water-wells productivity and lineaments morphometry: Selected zones from Lebanon. Nordic Hydrology 38: 178-201.

Sheldon J.C., 1975. The reclamation of slate waste. Nature Wales 14: 160-168.

Smyth C.R., 1997. Native legume transplant survivorship and subsequent seedling recruitment on unamended coal mine soils in the Canadian Rocky Mountains. Mountain Research and Development 17(2): 145-157.

Stehouwer R., Day R., Macneal E., 2006. Nutrient and trace element leaching following mine reclamation with biosolids. Journal of Environmental Quality 35: 1118-1126.

Stifeev A.I., Golovastikova A.V., Bessonova E.A., 2011. Izmenenie sostava i struktury mikrobnogo soobshchestva v usloviyah tekhnogennogo landshafta otvalov mihajlovskogo GOKa KMA. Vestnik Kurskoj gosudarstvennoj sel'skohozyajstvennoj akademii 4(4): 40-41 (in Russian).
Sumina O.I., 2013. Formirovanie rastitel'nosti na tekhnogennyh mestoobitaniyah Krajnego Severa Rossii. SPb, Infonavigator: 339 pp. (in Russian).

Tischew S., Kirmer A., 2007. Implementation of basic studies in the ecological restoration of surface-mined land. Restoration Ecology 15: 321-325.

Tormo J., Bochet E., Garcia-Fayos P., 2007. Roadfill revegetation in semiarid Mediterranean environments. Part II: Topsoiling, species selection, and hydroseeding. Restoration Ecology 15(1): 97-102.

Tormo J., Bochet E., Garcia-Fayos P., 2007. Roadfill revegetation in semiarid Mediterranean environments. Part II: Topsoiling, species selection, and hydroseeding. Restoration Ecology 15(1): 97-102 (doi: 10.1111/j.1526-100X.2006.00194.x).

Tsitovich I.K., 1994. Kurs analiticheskoj himii. Moscow: 495 pp. (in Russian).

Williamson J., Rowe E., Rendell T., Healey J., Jones D., Nason M., 2003. Restoring habitats of high conservation value after quarrying: best practice manual. Institute of Environmental Science, University of Wales, Bangor.: 40 pp.

Yarwood S., Wick A., Williams M., Daniels W.L., 2015. Parent material and vegetation influence soil microbial community structure following 30-years of rock weathering and pedogenesis. Microbial Ecology 69(2): 383-394 pp. (doi: 10.1007/ s00248-014-0523-1).

Zhang C., Xue S., Liu G.B., Zhang C.S., 2011. Effects of slope aspect on soil chemical and microbial properties during natural recovery on abandoned cropland in the Loess plateau, China. Progress in Environmental Science and Engineering 356-360: 2422-2429 (doi: 10.4028/www.scientific.net/ AMR.356-360.2422).

Received: June 15, 2018

Accepted: February 5, 2019

Associated editors: P. Hulisz, J. Wyszkowska

\section{Rekonstrukcja pokrywy glebowo-roślinnej i różnorodności mikrobiologicznej w kamieniołomie wapienia Pechurki (Obwód Leningradzki, Rosja)}

Streszczenie: Wzrost działalności górniczej nieodłącznie wiąże się z zaburzeniami ekosystemów i ich degradacją. Obszarom poprzemysłowym i powydobywczym można nadać nowe właściwości, aby zapewnić im samowystarczalność i możliwość rozwoju w naturalne środowiska. Kompleksowe badania pokrywy roślinnej i glebowej przeprowadzono w jednym z największych kamieniołomów wapienia w Obwodzie Leningradzkim w Rosji. Teren badań był objęty zarówno spontaniczną sukcesją, jak i planową rekultywacją w kierunku leśnym. Oszacowano skład gatunkowy i pokrycie roślinności dla różnych zbiorowisk roślinnych w obrębie każdego ekotypu. Przedstawiono również charakterystykę właściwości gleb na każdej powierzchni badawczej. Stwierdzono, że główne różnice między powierzchniami wynikały z ich położenia w krajobrazie. Na obszarach płaskich stwierdzono niską bioróżnorodność będącą efektem rekultywacji biologicznej. W miejscach, na których zachodziła naturalna sukcesja, poziom różnorodności biologicznej był natomiast zauważalnie wyższy. Z punktu widzenia ochrony bioróżnorodności oraz korzyści ekonomicznych (koszty rekultywacji), spontaniczna sukcesja na obszarach powydobywczych wapienia wypada korzystniej w zestawieniu z planową rekultywacją leśną. Na podstawie badań emisji $\mathrm{CO}_{2} \mathrm{z}$ kamieniołomu (wynikającego zarówno $\mathrm{z}$ wietrzenia węglanów, jak i oddychania organizmów glebowych), a także poziomu sekwestracji $\mathrm{CO}_{2} \mathrm{z}$ atmosfery stwierdzono, że zachowanie pewnych form krajobrazowych w dawnych kamieniołomach może pomóc w zmniejszeniu zawartości $\mathrm{CO}_{2} \mathrm{w}$ atmosferze.

Słowa kluczowe: rekultywacja, kamieniołomy wapienne, różnorodność biologiczna, gleby technogeniczne 